Undas Vol 12. , Nomor 1, Juni $2016: 1--16$

\title{
PELANGGARAN PRINSIP KERJA SAMA DALAM WACANA HUMOR KISAH-KISAH SARAWIN
}

\author{
Principle of Cooperation in Violation of Humor Stories Wacana Sarawin
}

\author{
Hestiyana \\ Balai Bahasa Kalimantan Selatan \\ Jalan Jenderal Ahmad Yani Km 32,2, Loktabat, Banjarbaru 70712 Kalimantan Selatan \\ Telepon (0511) 4772641, Pos-el: hestiyana21@gmail.com
}

\begin{abstract}
Abstrak: Penelitian ini bertujuan untuk mendeskripsikan bentuk pelanggaran prinsip kerja sama dalam wacana humor kisah-kisah Sarawin. Penelitian ini menggunakan metode deskriptif dengan pendekatan kualitatif. Dalam penelitian ini dilakukan tiga langkah kerja, yaitu tahap penyediaan data; tahap analisis data; dan tahap penyajian hasil analisis data. Dalam penyediaan data dilakukan pemilihan objek penelitian, yaitu Kisah-Kisah Sarawin Cerita-Cerita Humor Tokoh Legendaris Dalam Bahasa Banjar oleh Syamsiar Seman. Dalam penyediaan data juga digunakan teknik catat, yaitu memilih teks dan mencatat data-data yang mengandung unsur pelanggaran prinsip kerja sama. Pada tahap analisis data, tuturan-tuturan yang mengandung unsur pelanggaran prinsip kerja sama diklasifikasikan berdasarkan bentuk-bentuk pelanggaran prinsip kerja sama. Hasil analisis data yang digunakan untuk memaparkan pelanggaran prinsip kerja sama ialah dengan metode informal, dengan penyajian berbentuk uraian kalimat. Dari hasil pembahasan ditemukan pelanggaran prinsip kerja sama, berupa pelanggaran maksim kuantitas, kualitas, relevansi, dan cara. Pelanggaran terhadap maksim kuantitas berupa pemberian kontribusi yang berlebih dari Sarawin serta tidak sesuai dengan yang diharapkan Kuntulir Belanda dan orang-orang yang menghadiri acara Maulid. Pelanggaran terhadap maksim kualitas berupa tuturan yang tidak sebenarnya diujarkan oleh Sarawin kepada istrinya dan temanteman Sarawin. Kemudian, pelanggaran terhadap maksim relevansi berupa tuturan yang diujarkan oleh Sarawin tidak relevan seperti yang diharapkan orang tua Sarawin. Pelanggaran maksim relevansi yang tidak ada hubungannya dengan konteks juga terdapat dalam tuturan Tuganal kepada Sarawin. Selanjutnya, pelanggaran terhadap maksim cara berupa tuturan yang tidak jelas dan mengalami kekaburan makna yang dituturkan oleh istri Sarawin kepada Sarawin serta tuturan Sarawin kepada anak Patuha. Semua bentuk pelanggaran prinsip kerja sama dalam wacana humor tersebut menyebabkan munculnya kelucuan atau kejenakaan.
\end{abstract}

Kata kunci: Wacana humor, tuturan, pelanggaran, prinsip kerja sama

Abstract: This study aimed to describe the form of violation of the principle of cooperation in discourse Sarawin humor stories. This research uses descriptive method with qualitative approach. In this study three working steps, namely the step of providing data; data analysis stage; and the stage presentation of the results of data analysis. In the provision of election data was the object of study, namely Stories Stories Sarawin Humor Legendary Figures in Banjar language by Syamsiar Seman. In the provision of engineering log data is also used, namely selecting the text and record data that contain elements of violation of the principle of cooperation. At this stage of data analysis, speech-speech that contains elements of violation of the principle of cooperation is classified based on the violation of the principle forms of cooperation. The results of the analysis of the data used to expose violations of the principle of cooperation is the informal method, with the presentation of the form of the sentence description. From the 
discussion found violations of the principles of cooperation, such as violation of the maxim of quantity, quality, relevance, and how. Violation of the maxim of quantity the form of contributions in excess of Sarawin and not as expected Kuntulir Dutch and the people who attended the event Mawlid. Violation of the maxim of quality in the form of speech that is not actually uttered by Sarawin to his wife and friends Sarawin. Then, a violation of the maxim of relevance in the form of speech uttered by Sarawin irrelevant as expected parents Sarawin. Violations relevance maxim that has nothing to do with the context of the speech is also available in Tuganal to Sarawin. Furthermore, a violation of the maxims of the way in the form of speech that are not clear and experiencing meaning vagueness manifested by Sarawin to Sarawin wife and child utterances Sarawin Patuha. All forms of violation of the principle of cooperation in the discourse of humor that led to the emergence humor or wit.

Key words: Discourse humor, speech, violation of the principle of cooperation

\section{PENDAHULUAN}

Setiap masyarakat tentunya memiliki cerita-cerita humor. Humor sebagai hasil budaya juga sebagai identitas masyarakat pendukungnya dan menjadi alat perekat relasi di dalam masyarakat. Hal ini menunjukkan bahwa komunikasi yang berupa humor ataupun lawakan-lawakan akan membawa masyarakatnya secara perspektif sosial dan budaya dipandang sebagai peranti dalam menjalin relasi atau hubungan.

Seseorang yang memiliki kemampuan tinggi dalam berbahasa jenaka dianggap semakin tinggi kemampuan dan kreativitasnya dalam berbahasa. Bahkan, seseorang yang telah mahir dalam memanfaatkan humornya semakin banyak relasi yang dikenalnya. Kemahiran seseorang dalam menciptakan komunikasi humor juga akan berdampak positif bagi dirinya dan orang lain karena humor mampu membawa seseorang untuk berkreativitas dan berinovasi melalui cerita-cerita humor tersebut.

Adanya kreativitas berbahasa dalam masyarakat memunculkan terjadinya penyampaian-penyampaian bahasa yang cenderung jenaka, melalui tuturantuturan yang bermakna pragmatis.
Dengan demikian, humor merupakan salah satu bentuk perwujudan dalam kemahiran kreativitas bahasa.

Humor hadir di tengah-tengah masyarakat sebagai obat pengusir dari berbagai permasalahan kehidupan. Hal ini seperti yang diungkapkan Danandjaja (dalam Astuti, 2006: 2) bahwa dengan humor manusia dapat menghadapi ketimpangan masyarakat dengan canda dan tawa. Dengan demikian, humor sebenarnya dapat dijadikan alat psikoterapi, terutama bagi masyarakat yang sedang berada dalam proses perubahan kebudayaan secara cepat.

Kemudian, Astuti (2006: 2) menambahkan bahwa humor, baik yang disajikan secara lisan maupun tulis, cenderung merupakan wacana hiburan karena penciptaannya ditujukan untuk menghibur pembaca. Di samping itu, humor dapat berfungsi sebagai wahana kritik sosial terhadap segala bentuk ketimpangan yang terjadi di tengah masyarakat.

Dengan demikian, humor sebagai salah satu bentuk kreativitas berbahasa dapat digunakan untuk menjalin komunikasi di masyarakat serta menjadi alat pengontrol kedekatan antar- 
masyarakat tersebut. Humor juga dapat digunakan sebagai bentuk sindiran ataupun saran kepada pihak-pihak tertentu.

Untuk memunculkan kreativitas berbahasa dalam humor atau lawakan, yakni dengan membuatnya menjadi bentuk-bentuk lain atau dengan melanggar prinsip kerja sama. Dengan pelanggaran-pelanggaran dalam prinsip kerja sama akan muncul kejenakaan tuturan dalam humor tersebut.

Di dalam cabang ilmu bahasa pragmatik dijelaskan juga bahwa sosok kejenakaan atau kelucuan itu dapat terjadi karena ada proses komunikasi yang sifatnya non-bonafide. Jadi lawakan-lawakan itu terjadi, pelesetanpelesetan bahasa itu terjadi, dan kejenakaankejenakaan lain dapat terjadi, lantaran telah terjadi pelanggaran-pelanggaran maksim atau seperangkat aturan umum di dalam bertutur sapa, yang sengaja dilakukan oleh penuturnya. Kenonbonafidean di dalam proses bertutur sapa itu terjadi lantaran orang tidak sepenuhnya mematuhi prinsip kerja sama (Rahardi, 2011:32).

Pendapat yang sama juga dikemukakan Astuti (2006: 2) bahwa humor sebenarnya bukanlah sekedar penyimpangan aspek semantis bahasa, tetapi penyimpangan kaidah pragmatik. $\mathrm{Hal}$ itu terjadi karena ingin memunculkan kejenakaan dalam humor.

Dengan demikian, dalam humor semua prinsip-prinsip kebahasaan di dalam pragmatik dilanggar dengan sengaja oleh penuturnya. Di samping itu, kejelasan dan keterusterangan suatu cerita dalam humor dilanggar sehingga yang muncul adalah kelucuan, kejenakaan, kekonyolan, tuturan yang tidak seperti diharapkan.
Kisah-kisah Sarawin merupakan ceritacerita humor tokoh legendaris dalam bahasa Banjar, tentunya dalam humor tersebut terkandung berbagai macam bentuk pelanggaran prinsip kerja sama. Hal inilah yang menarik untuk dikaji, bahwa wacana humor mengandung pelanggaran- pelanggaran prinsip kerja sama. Di samping humor yang terdapat dalam Kisah-kisah Sarawin yang menggambarkan kehidupan sosial budaya masyarakat Banjar.

Penelitian yang terkait dengan prinsip kerja sama sudah banyak banyak dilakukan, di antaranya Prinsip Kerja Sama dalam Transaksi Jual Beli di Pasar Martapura oleh Jahdiah (2013), Pelanggaran Prinsip Kerja Sama dalam Wacana Humor Break Boss Surat Kabar Harian Cenderawasih Pos Papua oleh S Mariati (2013), Penerapan Prinsip Kerja Sama dalam Novel di Bawah Cahaya Langit Negeri Seribu Menara Karya Mittahur Rahman El Banjary oleh Jahdiah (2014), dan Penyimpangan Prinsip Kerja Sama dalam Kolom Berita Singkat Sepak Bola (Soccer Short) Surat Kabar Harian Banjarmasin Post (Suatu Kajian Pragmatik) oleh Yulianto (2015).

Hingga saat ini, penelitian khusus yang membahas pelanggaran prinsip kerja sama dalam wacana humor kisahkisah Sarawin belum ditemukan. Padahal, hal tersebut merupakan fenomena kebahasaan yang terjadi di masyarakat Banjar. Dengan munculnya tokoh Sarawin dalam cerita-cerita humor tokoh legendaris memberikan warna tersendiri dalam telaah kebahasaan. Di samping itu, tokoh Sarawin merupakan tokoh legendaris masyarakat Banjar yang banyak mengangkat kisah-kisah kehidupan sosial budaya masyarakat 
Banjar. Tentunya, kisah-kisah Sarawin ini merupakan wacana humor yang tak luput dari pelanggaran-pelanggaran prinsip kerja sama karena ingin memunculkannya unsur kelucuan atau kejenakaan. Di dalam humor kisah-kisah Sarawin juga banyak informasi yang disampaikan secara tidak langsung sehingga untuk memahaminya diperlukan pemahaman pragmatik.

Berdasarkan latar belakang tersebut, pokok permasalahan dalam penelitian ini adalah bagaimanakah bentuk pelanggaran prinsip kerja sama dalam wacana humor kisah-kisah Sarawin? Tujuan penelitian ini adalah untuk mendeskripsikan bentuk pelanggaran prinsip kerja sama dalam wacana humor kisah-kisah Sarawin.

Diharapkan hasil penelitian ini bermanfaat secara teoritis, yaitu mampu menjadi informasi yang lebih mendalam mengenai pelanggaran prinsip kerja sama dalam wacana humor kisah-kisah Sarawin. Manfaat secara praktis, yaitu hasil penelitian ini tentunya dapat dijadikan acuan bagi penelitianpenelitian selanjutnya.

\section{KERANGKA TEORI}

Humor merupakan sebuah bentuk komunikasi yang mengandung pelanggaranpelanggaran prinsip kerja sama. Hal ini bertujuan untuk memunculkan kelucuan atau kejenakaan. Jadi dalam humor, prinsip-prinsip kebahasaan di dalam pragmatik semuanya dilanggar dengan sengaja oleh penuturnya.

Dalam pendekatan pragmatik, humor pada hakikatnya adalah penyimpangan dua jenis implikatur, yakni implikatur konvensional dan implikatur pertuturan (Wijana dalam Astuti, 2006: 10). Yang pertama menyangkut makna bentuk-bentuk linguistik, sedangkan yang kedua menyangkut elemen- elemen wacana yang menurut Grice (dalam Astuti, 2006: 10) harus mematuhi prinsipprinsip percakapan.

Rustono (dalam Astuti, 2006: 10) mengemukakan bahwa humor itu hanyalah sebuah alat karena peranan dan nilainya bergantung pada tujuan dan pemanfaatan oleh pemakainya. Kemudian Aple (dalam Astuti, 2006: 10) mengemukakan bahwa humor adalah segala bentuk rangsangan, baik verbal maupun nonverbal, yang berpotensi memancing senyum dan atau tertawa penikmatnya. Rangsangan itu merupakan segala bentuk tingkah laku manusia yang dapat menimbulkan rasa gembira, geli, atau lucu pihak pendengar, penonton, dan pembaca.

Humor dapat membuat orang tertawa apabila mengandung satu atau lebih dari keempat unsur, yaitu kejutan, yang mengakibatkan rasa malu, ketidakmasukakalan, dan yang membesar-besarkan masalah. (Claire dalam Astuti, 2006: 10). Selanjutnya, Suprana (dalam Astuti, 2006: 10) menyatakan bahwa humor hanyalah satu bentuk komunikasi yang di dalamnya terdapat suatu stimulus pada suatu tingkat kompleksitas yang tinggi menghasilkan respon yang teramalkan dan tiruan pada tingkat refleks psikologis.

Monro (dalam Rustono, 1998: 51) menyatakan bahwa ada sepuluh penyebab terjadinya humor, yaitu: (1) pelanggaran terhadap sesuatu yang biasa; (2) pelanggaran terlarang atas sesuatu atau 
peristiwa yang biasa; ketaksenonohan; (4) kemustahilan; (5) permainan kata; (6) bualan; (7) kemalangan; (8) pengetahuanpemikiran-keahlian; (9) penghinaan terselubung; dan (10) pemasukan sesuatu ke dalam situasi lain. tentunya penyebab kelucuankelucuan tersebut didukung dengan ekspresi wajah atau gestur pelakunya.

Dengan demikian, humor merupakan sebuah alat yang digunakan untuk memberikan rangsangan segala bentuk tingkah laku manusia yang dapat menimbulkan rasa gembira, geli, atau lucu pihak pendengar, penonton, dan pembaca. Dapat dikatakan pula bahwa humor menjadi salah satu sarana hiburan.

Humor digemari masyarakat tidak hanya berfungsi sebagai sarana untuk menghibur saja, tetapi juga sebagai bentuk pengungkapan kenyataan-kenyataan hidup yang terjadi di masyarakat. Hal ini seperti yang dikemukakan Herawati (2007: 7) bahwa humor adalah suatu rangsangan yang dapat menyentuh perasaan penikmat. Humor dapat digunakan sebagai alat untuk mengekspresikan gagasan, pikiran, atau perasaan seseorang sehingga sasaran humor akan tersentuh perasaannya. Sebagai akibatnya, yang bersangkutan dapat tersenyum, tertawa, atau geli. Humor tidaklah sekadar berupa penyebab munculnya reaksi tersenyum atau tertawa, tetapi dapat juga berupa kemampuan menghibur dan menggelikan melalui ujaran atau tulisan.
Humor merupakan salah satu bentuk wacana. Wacana humor itu sendiri termasuk dalam wacana hiburan karena penciptaannya yang ditujukan sebagai sarana penghibur. Di dalam wacana humor juga terdapat serentetan kalimat-kalimat yang digunakan untuk menyatakan hubungan antarproposisi yang membentuk satu kesatuan. Hal ini seperti yang diungkapkan Moeliono, dkk (dalam Djajasudarma, 2012: 3) bahwa hubungan antarunsur yang membentuk wacana adalah yang disebut rentetan kalimat yang berkaitan sehingga terbentuklah makna serasi di antara kalimat-kalimat itu.

Di dalam wacana humor, prinsip-prinsip kerja sama sengaja dilanggar oleh penuturnya. Hal itu dilakukan karena ingin memunculkan kejenakaan dalam humor. Padahal, percakapan akan berlangsung dengan baik, apabila penutur dan lawan tutur sama-sama mentaati prinsip-prinsip kerja sama seperti yang dikemukakan oleh Grice (dalam Chaer, 2010: 34). Prinsip tersebut disebut maksim, yaitu berupa pernyataan ringkas yang mengandung ajaran atau kebenaran. Setiap penutur harus mentaati keempat maksim kerja sama sebagai berikut:

a. maksim kuantitas (maxim of quantity), maksim ini menghendaki setiap peserta tutur hanya memberikan kontribusi yang secukupnya saja atau sebanyak yang dibutuhkan oleh lawannya. Jadi jangan berlebihan.

b. maksim kualitas (maxim of quality), maksim ini menghendaki agar peserta pertuturan itu mengatakan hal yang sebenarnya, hal yang sesuai dengan data dan fakta.

c. maksim relevansi (maxim of relevance), maksim ini mengharuskan setiap peserta pertuturan memberikan kontribusi yang relevan dengan masalah atau tajuk pertuturan.

d. maksim cara (maxim of manner), maksim ini 
mengharuskan penutur dan lawan tutur berbicara secara langsung, tidak kabur, tidak ambigu, tidak berlebih-lebih dan runtut.

Selanjutnya, Grice (dalam Chaer, 2010: 38) menyodorkan prinsip kerja sama dalam pertuturan membuat analogi tentang keempat maksimnya sebagai berikut:

a) maksim kuantitas, kalau saya memerlukan dua buah obeng, maka kontribusi yang diharapkan adalah Anda memberi dua buah obeng, bukan tiga atau satu.

b) maksim kualitas, kalau saya memerlukan gula untuk adonan kua, maka saya tidak mengharapkan Anda memberikan garam atau tepung. Kalau saya membutuhkan sendok teh, maka saya tidak mengharapkan Anda memberikan sendok makan.

c) maksim relevansi, bila saya sedang mencampur bahan-bahan adonan kue maka saya tidak mengharapkan Anda memberikan kain oven walaupun benda yang terakhir ini saya butuhkan pada saatnya nanti.

d) maksim cara, saya mengharapkan teman kerja sama memahami kontribusi yang harus dilakukannya dan melaksanakannya secara rasional.

Dengan analogi itu barangkali konsep keempat maksim lebih dapat dipahami.

\section{METODE PENELITIAN}

Metode yang digunakan dalam penelitian ini adalah metode deskriptif dengan pendekatan kualitatif. Penelitian kualitatif ialah prosedur penelitian yang menghasilkan data deskriptif berupa kata-kata tertulis atau lisan tentang orang-orang atau perilaku yang diamati (Bogdan dan Taylor dalam Moleong, 2002: 4).
Dalam penelitian ini dilakukan tiga langkah kerja, yaitu: (1) tahap penyediaan data; (2) tahap analisis data; dan (3) tahap penyajian hasil analisis data seperti yang diungkapkan Sudaryanto (2015: 6). Dalam penyediaan data dilakukan pemilihan objek penelitian, yaitu Kisah-Kisah Sarawin Cerita-Cerita Humor Tokoh Legendaris Dalam Bahasa Banjar oleh Syamsiar Seman. Kemudian, dalam tahap penyediaan data juga digunakan teknik catat, yaitu memilih teks dan mencatat data-data yang mengandung unsur pelanggaran prinsip kerja sama.

Pada tahap analisis data, tuturan-tuturan yang mengandung unsur pelanggaran prinsip kerja sama diklasifikasikan berdasarkan bentuk-bentuk pelanggaran prinsip kerja sama. Sehubungan dengan tahap analisis data Sudaryanto (dalam Nurmiah, 2014: 200) menyatakan bahwa hasil analisis data dapat disajikan dengan menggunakan dua metode, yaitu metode informal dan metode formal. Dalam penelitian ini, hasil analisis data yang digunakan untuk memaparkan pelanggaran prinsip kerja sama ialah metode informal, yaitu dengan penyajian berbentuk uraian kalimat.

\section{ANALISIS DAN PEMBAHASAN}

Berdasarkan data yang diperoleh, dapat dideskripsikan pelanggaran prinsip kerja sama dalam Kisah-kisah Sarawin. Berikut hasil analisis data pelanggaran prinsip kerja sama dalam Kisah-Kisah Sarawin Cerita-Cerita Humor Tokoh Legendaris dalam Bahasa Banjar. 
Undas Vol 12., Nomor 1, Juni 2016 : 1--16

\section{Pelanggaran Maksim Kuantitas}

Data 1

Wayah nitu pas pukul sablas. Sarawin lalu lalu maambil pamukul luncing, tarus mancatuk luncing saling gancangan: tingting, tingting, tingting, tingting, tingting, tingting,.....

Tuan Kuntulir takajut. Kanapa luncing dicatuk 12 kali, maka ari hanyar pukul sablas. Rupanya tuan Kuntulir maitung haja inya.

Sarawin dikiyau. Manggatar-gatar Sarawin masuk katakutanan inya.

"Hupperdum kamu urang! Kamu urang bodok sekali. Itu pukul sebelas kamu pukul itu lonceng 12 kali! Bodok!", ujar Kuntulir sarik.

Sarawin kada sing bunyian kana pardum tuan Kuntulir. Kada tahu lagi inya macam-macam basa Walanda nang diucapkan Kuntulir nitu.

Sarawin duduk maungut. Tahu-tahu imbah nitu diambilnya lagi pancatuk luncing dicatuknya.......ting.......sakali saling gancangan.

Tuan Kuntulir bakuciak di dalam kamar kasarikan.

"Hupperdum itu urang. Kenapa itu lonceng dipukul lagi! Bodok! Mari ke sini itu urang bodok! Hupperdum!"

Sarawin masuk ka kamar tuan

Kuntulir, lalu baucap:

Catukan nang sabigi nitu tuanai maambil sabigi nang duabalas tadi. Jadi 12 kurang sabigi sisa 11. Itu artinya pukul sablas".

"Hupperdum kamu urang. Bikin rusak ini kantor saya!". Tuan Kuntulir mahampas ka tupinya kasarikan. Manciling matanya handak pacul. (Dipardum Tuan Kuntulir, hlm. 1112).

Terjemahan:
"Saat itu tepat pukul sebelas. Sarawin lalu mengambil pemukul lonceng, terus memukul lonceng dengan keras: tingting, tingting, tingting, tingting, tingting, tingting,,....

Tuan Kuntulir terkejut. Kenapa lonceng dipukul 12 kali, sedangkan baru pukul sebelas. Rupanya Tuan Kuntulir menghitung saja dia. Sarawin dipanggil. Dengan gugup Sarawin masuk ketakutan dia.

"Hupperdum kamu orang! Kamu orang bodoh sekali. Itu pukul sebelas kamu pukul itu lonceng 12 kali! Bodoh!", ucap Kuntulir marah.

Sarawin tidak bisa berbicara lagi karena dimarahi Tuan Kuntulir. Tidak tahu lagi dia macam-macam bahasa Belanda yang diucapkan Kuntulir itu.

Sarawin duduk terdiam. Tahu-tahu setelah itu diambilnya lagi pencatuk lonceng lalu dicatuknya........ting........sekali dengan keras.

Tuan Kuntulir berteriak di dalam kamar dengan marah.

"Hupperdum kamu orang! Kenapa itu lonceng dipukul lagi! Bodoh! Mari ke sini itu urang bodoh! Hupperdum!"

Sarawin masuk ka kamar tuan Kuntulir, lalu berucap:

"Pukulan yang sebigi itu tunai untuk mengambil sebigi yang dua belas tadi. Jadi 12 kurang sebigi sisa 11. Itu artinya pukul sebelas."

"Hupperdum kamu orang. Bikin rusak ini kantor saya!". Tuan Kuntulir menghempaskan topinya dengan marah sekali. Melotot matanya mau lepas". (Dipardum Tuan Kuntulir, hlm. 11-12).

Data (1) di atas tampak percakapan terjadi antara Sarawin dengan Kuntulir Belanda. Sarawin 
bekerja di kantor Kuntulir menjaga di halaman kantor dan bertugas memukul lonceng gantung bila sudah tiba waktunya. Tuan Kuntulir sebagai atasan Sarawin marah sekali karena kesalahan Sarawin yang memukul lonceng sebanyak dua belas kali, padahal jam baru menunjukkan pukul sebelas malam. Kemudian yang menambah Tuan Kuntulir murka, ketika Sarawin memukul lonceng lagi sebanyak satu kali. Tuturan Sarawin yang membela diri, yaitu Catukan nang sabigi nitu tuanai maambil sabigi nang duabalas tadi. Jadi 12 kurang sabigi sisa 11. Itu artinya pukul sablas". Tuturan Sarawin secara kuantitas tidak sesuai dengan yang dibutuhkan Tuan Kuntulir. Kontribusi yang diberikan Sarawin terlalu banyak. Seandainya, tuturan Sarawin "Maap Tuan aku kira sudah jam dua belas", "Maaf Tuan saya kira sudah jam dua belas", tuturan tersebut sudah sesuai dengan maksim kuantitas. Tuturan Sarawin yang melanggar maksim kuantitas ini menjadi penyebab munculnya humor atau kelucuan dalam wacana humor tersebut.

\section{Data 2}

"Ayu Bacakan tarus sa atiril", ujar urang manyuruh Sarawin.

"Asa ngalih nih aku mambaca", ujar Sarawin.

"Ai jangan basusupanan. Baca ha!", ujar urang pulang manyuruh.

"Aku kada tabiasa", ujar Sarawin.

Cangang urang barataan lawan Sarawin. Imbah nitu ada pulang nang manyuruh:
"Baca haja bagagamatan. Inya tuntung haja paampihannya"."Ini barataan banyak minta maap haja. Kada tabiasa mambaca kitab Barjanji. Tapi amun urusan mamukul babun...nih, batakun haja lawan kawan nang dihigaku ni", ujar Sarawin.

Lalu mandarauai urang tatawaan. Haji Isul nang ampun gawi mulut nitu lucut jua tatawa". (Tulak ka Urang Mulut, hlm. 18).

Terjemahan:

"Ayu bacakan terus sa atiril", kata orang menyuruh Sarawin.

"Rasa susah nih aku membaca", kata Sarawin.

"Ai jangan malu-malu. Baca saja!", kata orang lagi menyuruh.

"Aku tidak terbiasa", kata Sarawin. Melihat orang semuanya dengan Sarawin. Setelah itu, ada lagi yang menyuruh:

"Baca saja pelan-pelan. Nanti selesai saja".

"Ini semuanya banyak minta maaf saja. Tidak terbiasa membaca Kitab Berjanji. Tapi kalau urusan memukul babun.....nih, bertanya saja dengan kawan yang di sampingku ini", kata Sarawin.

Kemudian tertawa orang semuanya. Haji Isul yang punya acara Maulud nitu tertawa juga terbahak-bahak. (Tulak ka Urang Mulut, hlm. 18).

Data (2) di atas merupakan percakapan antara Sarawin dengan orang-orang yang menghadiri acara Maulid Nabi di rumah Haji Isul. Di acara tersebut semua tamu yang hadir disuruh membaca Kitab Berjanji yang dibaca bergantian. Ketika giliran Sarawin yang disuruh membaca, Sarawin berucap "Asa ngalih nih aku mambaca", ujar 
Sarawin dan tuturan Sarawin yang berbunyi "Ini barataan banyak minta maap haja. Kada tabiasa mambaca kitab Barjanji. Tapi amun urusan mamukul babun...nih, batakun haja lawan kawan nang dihigaku ni", ujar Sarawin melanggar prinsip kerja sama maksim kuantitas. Tuturan Sarawin secara kuantitas tersebut tidak sesuai dengan jawaban yang diharapkan orang-orang atau tamu yang menghadiri acara tersebut. Kontribusi yang diberikan Sarawin terlalu banyak. Seandainya, tuturan Sarawin dalam wacana humor tersebut hanya berbunyi "maapaku kada bisa", "maaf saya tidak bisa", tuturan tersebut sudah sesuai dengan maksim kuantitas sehingga tidak ada lagi percakapan lainnya. Akan tetapi, ketika disuruh membaca Kitab Berjanji tersebut Sarawin menjawab dengan "Asa ngalih nih aku mambaca" "Rasa susah nih saya membaca" dan tuturan "Kada tabiasa mambaca kitab Barjanji" "Tidak terbiasa membaca Kitab Berjanji". Dengan tuturan Sarawin yang melanggar prinsip kerja sama tersebut menjadi penyebab munculnya kelucuan dalam wacana humor tersebut.

\section{Pelanggaran Maksim Kualitas}

\section{Data 3}

Naah....kaina kita pasang di hadapan rumah, papan litir nang batulisan ganal-ganal sampai kaliatan lima puluh mitir kawa dibaca urang.

"Macam-macam abahnya naya. Litir nangapa pulang".
"Dangarakan umanya. Litir nitu kaya ini bunyinya: Sarawin Tukang Sunat, Ahli Manyunat secara Tradisiunal".

"Hahahahaaaa......", mangangkang nang bini tatawa.

"Nangapa ikam tatawa kaya damintu umanya?", ujar Sarawin.

"Andika musti ada sabuting nang kada tahu nang dirahasiakan ulih habib abahnyaai. Bacaan tatawarannya".

"Hemmmmm, jangan dikira umanyaai. Bacaan tawarannya nitu aku sudah tahu umanyaai. Tawarannya nitu handap haja bacaannya".

"Umpat mandangar pang aku abahnya?"

"Dangarakan aku mambacaakan: Tawar, tawar tawir. Tatawar bigi palir......hapuk umanyaai!". (Sarawin Handak Jadi Tukang Sunat, hlm. 1516).

Terjemahan:

“Naah.... nanti kita pasang di depan rumah, papan pengumuman dengan tulisan yang besar-besar sampai kelihatan lima puluh meter bisa dibaca orang.

“Macam-macam suaminya itu. Ada apa dengan papan pengumuman lagi".

"Dengarkan istriku. Papan itu bunyinya: Sarawin Tukang Sunat, Ahli Menyunat secara Tradisional". "Hahahahaaaa......", istrinya tertawa terbahak-bahak.

"Kenapa kamu tertawa seperti itu istriku?", ucap Sarawin.

"Anda mesti ada satu yang tidak tahu yang dirahasiakan oleh habin suamiku. Tawarannya itu pendek saja bacaannya".

"Ikut mendengar ya saya suamiku?"

"Dengarkan saya membacakan: Tawar, tawar tawir. Tatawar bigi palir......hapuk umanyaai!". 
(Sarawin Handak Jadi Tukang Sunat, hlm. 15-16).

Data (3) di atas tampak percakapan antara Sarawin dengan istrinya dengan topik pembicaraan Sarawin yang ingin membuka praktik tukang sunat tradisional.

Tuturan

Sarawin"Hemmmmm, jangan dikira umanyaai. Bacaan tawarannya nitu aku sudah tahu umanyaai. Tawarannya nitu handap haja bacaannya"serta tuturan Sarawin ketika istrinya bertanya ingin mendengar tawar sunat tradisional, yaitu "Dangarakan aku mambacaakan: Tawar, tawar tawir. Tatawar bigi palir.....hapuk umanyaai!". Tuturan Sarawin tersebut melanggar maksim kualitas. Sarawin menuturkan sesuatu yang salah dan tidak memiliki buktibukti yang konkret dengan yang diucapkannya. Seandainya tuturan Sarawin tersebut "kaina aku cari tahu tawaran basunat nitu", tidak akan melanggar maksim kualitas. Namun, tuturan Sarawin yang melanggar maksim kualitas tersebut mempunyai fungsi sebagai penunjang pengungkapan humor.

\section{Data 4}

"Langsat nangapa nah nang banyak bangkung", ujar Matali.

"Langsat Halabiu!", ujar Tuganal.

Lalu tatawaan bubuhannya.

"Jangan sasambat-sambat Halabiu ai", ujar Sarawin.

"Mantangan aku tutus urang Halabiu lalu disindir-sindir".

"Inya urang Halabiu harat pandir.

Hahahahaaaaa......"

"Iwak nangapa nah nang datang di atas puhun?", ujar Sarawin.

"Asa kadada iwak datang di atas puhun", ujar Nangacil.
"Musti ada! Bataruh kulawan. Bubujuran datang di atas puhun".

"Gong nah aku. Asa kada dapat manangguh", ujar Patuha.

"Amun gong kusambat nah", ujar Sarawin.

"Ayu sudah barataan gong, kada dapat!", ujar Matali.

"Iwak mandai kulit tiwadak, bungulai!", ujar Sarawin.

"Bah, dasar babanaran. Bujur ujar Sarawin. Iwak kulit ngarannya".

Imbah nitu badiri Tuganal sambil manunjuk ka subarang.

"Liat Sarawin! Bini ikam tu di subarang mambawa tiwadak talu bigi. Kulitnya gasan baulah iwak pulang."

"Hahahahaaaaaaaaaaaa............!!!"

(Kulit Buah Tiwadak, hlm. 30).

Terjemahan:

"Langsat apa ya yang banyak bangkung", kata Matali.

"Langsat Halabiu!", kata Tuganal.

Kemudian mereka tertawa.

"Jangan bilang-bilang Halabiu", kata Sarawin.

"Mentang-mentang aku keturunan orang Halabiu lalu disindir-sindir".

"Orang Halabiu pandai berbicara. Hahahahaaaa...."

"Ikan apa ya yang datang dari atas pohon?" ujar Sarawin.

"Pasti ada! Bertaruh kulawan. Benar datang di atas pohon".

"Aku tidak tahu. Sepertinya aku tidak bisa menjawab", kata Patuha.

"Kalau tidak ada yang tahu kusebut ya", kata Sarawin.

"Iya semua tidak ada yang tahu!", kata Matali

"Ikan mandai kulit cempedak, bodoh!", kata Sarawin.

"Wah, memang benar. Benar kata Sarawin. Ikan kulit namanya". Setelah itu Tuganal berdiri sambil menunjuk ke seberang. 
“Lihat Sarawin! Istrimu di seberang membawa cempedak tiga biji. Kulitnya untuk membuat ikan lagi."

"Hahahahaaaaaaa

(Kulit

Buah Tiwadak, hlm. 30).

Data (4) di atas tampak percakapan antara Sarawin dengan teman-temannya, yakni Matali, Tuganal, Nangacil, dan Patuha. Topik pembicaraan mereka adalah tebak-tebakan buah. Tuturan Sarawin ketika menanyakan kepada teman-temannya tersebut, yaitu "Iwak nangapa nah nang datang di atas puhun?", ujar Sarawin "Ikan apa nah yang datang di atas pohon?" kata Sarawin dan jawaban Sarawin atas pertanyaan tebak-tebakannya "Iwak mandai kulit tiwadak, bungulai!", ujar Sarawin "Ikan mandai kulit cempedak, bodoh!" kata Sarawin melanggar maksim kualitas karena pertanyaannya yang tidak masuk akal. Seandainya tuturan Sarawin tersebut berbunyi "Iwak apa nang paling aku katujui?" "Ikan apa yang paling saya sukai?", tuturan tersebut sudah sesuai dengan maksim kualitas karena menanyakan sesuatu yang masuk akal. Akan tetapi, tuturan Sarawin berupa pertanyaan tebak-tebakan tersebut berfungsi sebagai penunjang kelucuan dalam humor tersebut.

\section{Pelanggaran Maksim Relevansi}

\section{Data 5}

Malam nitu nang kuitan dua laki bini dudukan pulang di ambin. Dalam hati Sarawin malam ini sudah kasampatan ni nang pahabisan.
"Ulun maai kada jadi tulak madam", ujar Sarawin.

"Bagusai! Kada apa-apa jua dicari bajauh-jauh", ujar bapanya.

"Sukuram. Badidiam di rumah sini haja", ujar umanya manyahut.

"Tapi maai, pilih antara dua. Pian handak rugi sadikit atau rugi banyak!", ujar Sarawin pina manciling mata.

Nang kuitan badua laki bini takajut.

"Nangapa rugi banyak? Nangapa rugi sadikit?" ujar umanya.

"Amun handak rugi banyak, kusalukut rumah". Umanya pucat muha. Nang bapa kalapasan puting ruku mandangar.

"Amun handak rugi sadikit biniakan ulun", ujar Sarawin. (Sarawin Handak Tulak Madam, hlm. 3-4).

Terjemahan:

"Malam itu kedua orang tuanya duduk-duduk di teras. Dalam hati Sarawin malam ini merupakan kesempatan yang terakhir.

"Ibu, saya tidak jadi pergi merantau", kata Sarawin.

"Bagus! Tidak ada juga yang dicari jauh-jauh", kata ayahnya.

"Syukur. Berdiam di rumah saja", kata ibunya menyahut.

“Tapi Bu, pilih antara dua. Engkau mau rugi sedikit atau rugwi banyak!", kata Sarawin dengan matamelotot.

Kedua orang tuanya terkejut.

"Apa yang rugi banyak? Apa yang rugi sedikit?" kata ibunya.

"Kalau ingin rugi banyak? Kubakar rumah". Muka ibunya pucat. Ayahnya terlepas puting rokok mendengar.

"Kalau mau rugi sedikit kawinkan saya". Ucap Sarawin. (Sarawin Handak Tulak Madam, hlm. 3-4).

Data (5) di atas, tampak terjadi percakapan antara Sarawin, ayah dan 
ibunya Sarawin di teras rumah. Sarawin mengungkapkan keinginannya untuk merantau yang membuat ayah dan ibunya sangat terkejut. Padahal keinginan yang diungkapkannya tersebut hanyalah sebuah kiasan kalau sebenarnya Sarawin minta dikawinkan. Dia merasa umur yang semakin tua dan teman-temannya sudah berkeluarga semua. Tuturan Sarawin "Tapi maai, pilih antara dua. Pian handak rugi sadikit atau rugi banyak!", ujar Sarawin pina manciling mata" dan tuturan yang berbunyi "Amun handak rugi banyak, kusalukut rumah", serta tuturan "Amun handak rugi sadikit biniakan ulun", ujar Sarawin, melanggar maksim relevansi.

Tuturan Sarawin tersebut tidak relevan atau tidak ada hubungannya dengan pertanyaan kedua orang tuanya. Kontribusi yang disumbangkan Sarawin tidak relevan dengan yang diharapkan kedua orang tuanya. Seandainya tuturan Sarawin berbunyi "Ulun kada jadi madam lantaran kada handak maninggalakan abah wan uma badua" "Saya tidak jadi merantau karena tidak ingin meninggalkan ayah dan ibu berdua" tidak melanggar maksim relevansi karena tuturan tersebut yang diharapkan kedua orang tuanya. Akan tetapi, pelanggaran maksim relevansi ini berfungsi untuk menciptakan kelucuan dalam wacana humor.

\section{Data 6}

"Nyaman lah guguduh tiwadak nitu?", ujar Sarawin batakun.

"Nyamanai!", ujar Patuha.

"Amun nang tukang jual bapadah nyaman tarusai. Nyaman lakas payu!", ujar Sarawin. Manciling mata Patuha disambat Sarawin kaya itu.
"Bujur haja, nyaman!", ujar Tuganal malawanakan.

"Amun handak, rasai ha. Apa nang mangguguduh naya urangnya balu". (Kulit Buah Tiwadak, hlm. 29).

Terjemahan:

"Enak ya cempedak goreng itu?", kata Sarawin bertanya.

"Enak!", kata Patuha

"Kalau penjual selalu bilang enak. Supaya cepat laku!", kata Sarawin. Melotot mata Patuha disebut Sarawin seperti itu.

“Benar saja, Enak!", kata Tuganal.

"Kalau mau, silakan di rasai. Apa yang membuatnya itu orangnya janda". (Kulit Buah Tiwadak, hlm. 29).

Data (6) terlihat percakapan antara Sarawin, Patuha, dan Tuganal di warung Patuha. Tuturan Tuganal yang berbunyi "Amun handak, rasai ha. Apa nang mangguguduh naya urangnya balu" "Kalau mau, dicoba rasanya. Apa yang membuatnya itu orangnya janda" melanggar maksim relevansi karena tuturan tersebut tidak relevan atau tidak ada hubungannya dengan pertanyaan yang diajukan Sarawin. Tuturan Tuganal tidak memberikan kontribusi yang dibutuhkan Sarawin sebagai penanya. Seandainya, tuturan Tuganal hanya berbunyi "Ih guguduhnya nyaman!" "Iya guguduhnya enak!" tidak melanggar maksim relevansi karena sesuai dengan harapan Sarawin sebagai penanya. Akan tetapi, tuturan Tuganal yang telah melanggar maksim relevansi tersebut mampu mengungkapkan kelucuan atau humor. 
Undas Vol 12., Nomor 1, Juni 2016 : 1--16

\section{Pelanggaran Maksim Cara}

\section{Data 7}

Bini Sarawin rahatan manggangan nangka di dapur. Sarawin datang tarus mandapati nang bini di dapur. Nang bini manjanaki Sarawin, lalu takurihing.

"Naah! Balangkaram abahnya limbah bapasang gigi palasu", ujar nang bini. "Jangan mamuji bahahadapan umanyaai! Nih ikam nangapa?"

"Ai, gangan nangka abahnyaai. Nyaman bacampur kapala minangin".

Sarawin manjanguk panci nang baisi gangan nangka, lalu banganga. Limbah banganga...pluk, ujar...gigi palasunya gugur ka gangan. (Sarawin Bagigi Palsu, hlm. 22).

Terjemahan:

"Istri Sarawin sedang memasak sayur nangka di dapur. Sarawin datang dan mendapati istrinya di dapur. Istrinya menatap Sarawin, kemudian tersenyum.

"Nah, semakin tampan suamiku setelah pasang gigi palsu". Kata sang istri.

"Jangan memuji di depanku istriku! Nih kamu apa?

"Ai, sayur nangka suamiku. Enak dicampur kepala ikan menangin".

Sarawin menengok ke panci yang berisi sayur nangka, lalu menganga. Setelah menganga...pluk, gigi palsu jatuh ke sayur. (Sarawin Bagigi Palsu, hlm. 22).

Data (7) di atas tampak percakapan antara Sarawin dan istrinya di dapur. Tuturan istri Sarawin yang berbunyi "Naah! Balangkaram abahnya limbah bapasang gigi palasu", ujar nang bini melanggar maksim cara karena tuturan tersebut memiliki makna yang kabur. Istri Sarawin memuji suaminya yang baru pulang dari memasang gigi palsu.
Ketika Sarawin melihat sayur nangka dan tanpa sengaja gigi palsu Sarawin lepas dan jatuh ke dalam sayur nangka tersebut. Hal ini menandakan bahwa gigi palsu yang dipasang Sarawin tidak berkualitas tinggi.

Seandainya tuturan istri Sarawin itu "Kyapa gigi palsu yang dipasang tadi, bagus hajalah?" "Bagaimana gigi palsu yang dipasang tadi, bagus saja kan?", tuturan tersebut tidak melanggar maksim cara karena dituturkan dengan makna yang jelas. Namun, tuturan istri Sarawin yang setengah mengejek itu menimbulkan kelucuan atau rasa humor tersendiri.

\section{Data 8}

"Nukar wadai nang mana pian?", ujar bibinian anum nang bajual.

"Hehe...wadai nang manis", ujar Sarawin. "Nang parlu manis dilihat dahulu, sual rasa nitu kaina dahulu, hehe....".

"Wadai ulun manis samunyaan, pian handak kalu?"

"Ikam manis kalulah, handak banar aku!"

"Bujur-bujur, pian handak nang mana?"

"Nang baampar, jadi pangantin lawan baantah di burit".

Babaya tuntung baucap nitu, takajut Sarawin. Tangannya dikacak ulih Patuha nang badiri di higa. Patuha nitu tutulian sadikit, jadi pandangarnya tasalah-salah.

"Kurang ajar ikam Sarawinai. Ikam tahulah, ni anakku. Inya jangan dihulut-hulut. Ikam tadi kudangar mamadahakan inya batambah manis, nang langkar, jadi pangantin baganal burit! Kurang ajar!" (Sarawin Handak Manukar Pabukaan, hlm. 24). 
Terjemahan:

“Beli kue yang mana?", kata wanita muda si penjual

"Heee, kue yang manis?" kata Sarawin. "Yang penting manis dilihat dahulu, soal rasa nanti dulu, heee....."

"Kue saya manis semuanya. Kamu mau kan?"

"Kamu manis ya, aku mau sekali".

"Sungguh, kamu mau yang mana?".

"Yang baampar, jadi pengantin dan baantah di burit".

Ketika selesai berkata, terkejut Sarawin. Tangannya dipegang oleh Patuha yang berdiri di samping. Patuha itu agak tuli, jadi pendengarannya agak salah-salah.

“Kurang ajar kamu, Sarawin. Kamu tahu, ini anakku. Dia jangan diledek. Kamu tadi kudengar mengatakan dia bertambah manis, cantik, jadi pengantin pantat bertambah besar! Kurang ajar!". (Sarawin Handak Manukar Pabukaan, hlm. 24).

Data (8) di atas tampak percakapan antara Sarawin, Patuha, anaknya yang sedang berjualan kue. Tuturan Sarawin yang berbunyi "Hehe...wadai nang manis", ujar Sarawin. "Nang parlu manis dilihat dahulu, sual rasa nitu kaina dahulu, hehe....", dan tuturan Sarawin "Ikam manis kalulah, handak banar aku!" serta tuturan Sarawin "Nang baampar, jadi pangantin lawan baantah di burit", melanggar maksim cara karena makna yang ditimbulkan dari tuturan tersebut tidak jelas. Padahal anak gadis Patuha yang sedang berjualan kue menanyakan dengan jelas kepada Sarawin kue apa yang ingin dibeli Sarawin dan menjelaskan bahwa kue yang dijualnya manis semua sesuai pertanyaan
Sarawin. Akan tetapi, Sarawin menanggapinya dengan makna yang kabur atau tidak jelas.

Seandainya, tuturan Sarawin langsung dan jelas menyampaikan maksudnya, yakni "Aku handak manukar wadai amparan tatak, sari pangantin lawan nang baantah di burit", tidak melanggar maksim cara karena tuturan ini memiliki makna yang jelas. Namun, dibalik pelanggaran maksim cara yang dilakukan Sarawin tersebut memunculkan kelucuan atau humor.

\section{PENUTUP}

Berdasarkan hasil pembahasan pelanggaran prinsip kerja sama dalam wacana humor kisah-kisah Sarawin dapat disimpulkan bahwa dalam wacana humor semua prinsip-prinsip kebahasaan di dalam pragmatik dilanggar dengan sengaja oleh penuturnya. Di samping itu, kejelasan dan keterusterangan suatu cerita dalam humor dilanggar bertujuan untuk memunculkan kelucuan atau kejenakaan.

Dalam wacana humor kisah-kisah Sarawin terdapat pelanggaran prinsip kerja sama, berupa maksim kuantitas, maksim kualitas, maksim relevansi, dan maksim cara. Pelanggaran terhadap maksim kuantitas berupa pemberian kontribusi yang berlebih dari Sarawin serta tidak sesuai dengan yang diharapkan Kuntulir Belanda dan orang-orang yang menghadiri acara Maulid. Pelanggaran terhadap maksim kualitas berupa tuturan yang tidak sebenarnya diujarkan oleh Sarawin kepada istrinya dan teman-teman Sarawin. Kemudian, pelanggaran terhadap maksim relevansi berupa 
tuturan yang diujarkan oleh Sarawin tidak relevan seperti yang diharapkan orang tua Sarawin. Pelanggaran maksim relevansi yang tidak ada hubungannya dengan konteks juga terdapat dalam tuturan Tuganal kepada Sarawin. Selanjutnya, pelanggaran terhadap maksim cara berupa tuturan yang tidak jelas dan mengalami kekaburan makna yang dituturkan oleh istri Sarawin kepada Sarawin serta tuturan Sarawin kepada anak Patuha. Semua bentuk pelanggaran prinsip kerja sama dalam wacana humor tersebut menyebabkan munculnya kelucuan atau kejenakaan.

\section{DAFTAR PUSTAKA}

Astuti, Wiwiek Dwi. 2006. Wacana Humor Tertulis: Kajian Tindak Tutur. Jakarta: Pusat Bahasa.

Chaer, Abdul. 2010. Kesantunan Berbahasa. Jakarta: Rineka Cipta.

Djajasudarma, T Fatimah. 2012. Wacana dan Pragmatik. Bandung: Refika Aditama.

Herawati. 2007. Wacana Humor dalam Bahasa Jawa. Yogyakarta: Balai Bahasa Yogyakarta.

Jahdiah. 2013. "Prinsip Kerja Sama dalam Transaksi Jual Beli di Pasar Martapura". Dalam Bunga Rampai Hasil Penelitian Kebahasaan, hlm. 25-45. Banjarbaru: Balai Bahasa Provinsi Kalimantan Selatan.

-. 2014. "Penerapan Prinsip Kerja Sama dalam Novel Di Bawah Cahaya Langit Negeri Seribu Menara Karya Mittahur Rahman El Banjary". Dalam Bunga Rampai Hasil PenelitianKebahasaan, hlm. 100-126. Banjarbaru: Balai Bahasa Provinsi Kalimantan Selatan.

Moleong, Lexy J. 2002. Metode Penelitian Kualitatif. Bandung: Remaja Bandung.

Nurmiah. 2014. “Implikatur Percakapan dalam Transaksi Jual Beli di Pasar Tradisional di Kota Palu". Dalam Multilingual Jurnal Kebahasaan dan Kesastraan XIII (2): 196-207. Balai Bahasa Provinsi Sulawesi Tengah.

Rahardi, Kunjana. 2011. Humor Ada Teorinya Bahasa dan Gaya Melawak. Yogyakarta: Pinus Book Publisher.

Rustono. 1998. Implikatur Percakapan sebagai Penunjang Pengungkapan Humor di dalam Wacana Humor Verbal Lisan Berbahasa Indonesia. Disertasi. Universitas Indonesia.

S Mariati Sitti. 2013. "Pelanggaran Prinsip Kerja Sama dalam Wacana Humor Break Boss Surat Kabar Harian Cenderawasih Pos Papua". Dalam Aksara Jurnal Bahasa dan Sastra, Volume 25 Nomor 2, hlm. 169-181. Denpasar: Balai Bahasa Provinsi Bali. 
Pelanggaran Prinsip Kerjasama dalam Wacana Humor Kisah-Kisah Sarawin (Hestiyana)

Seman, Syamsiar. 2005. Kisah-Kisah Sarawin Cerita-Cerita Humor Tokoh Legendaris Dalam Bahasa Banjar. Banjarmasin: Lembaga Pendidikan Banua Banjarmasin.

Sudaryanto. 2015. Metode dan Aneka Teknik Analisis Bahasa Pengantar Penelitian Wahana Kebudayaan secara Linguistis. Yogyakarta: Sanata Dharma University Press.

Yulianto, Agus. 2015. “Penyimpangan Prinsip Kerja Sama dalam Kolom Berita Singkat Sepak Bola (Soccer Short) Surat Kabar Harian Banjarmasin Post (Suatu kajian Pragmatik)". Dalam Bunga Rampai Hasil Penelitian Kebahasaan, hlm. 52-70. Banjarbaru: Balai Bahasa Provinsi Kalimantan Selatan. 